\title{
Model pendidikan Kader Berbasis Wawasan Kebangsaan di Era- Post-Trust: Studi Kasus Organisasi Ikatan Mahasiswa Muhammadiyah Universitas Muhammadiyah Maluku Utara
}

\author{
Rahmat Abd Fatah ${ }^{1}$, Julhija Rasai \\ 12 Universitas Muhammadiyah Maluku Utara (UMMU) Indonesia \\ Korespondensi: rahmatabdfatah@gmail.com
}

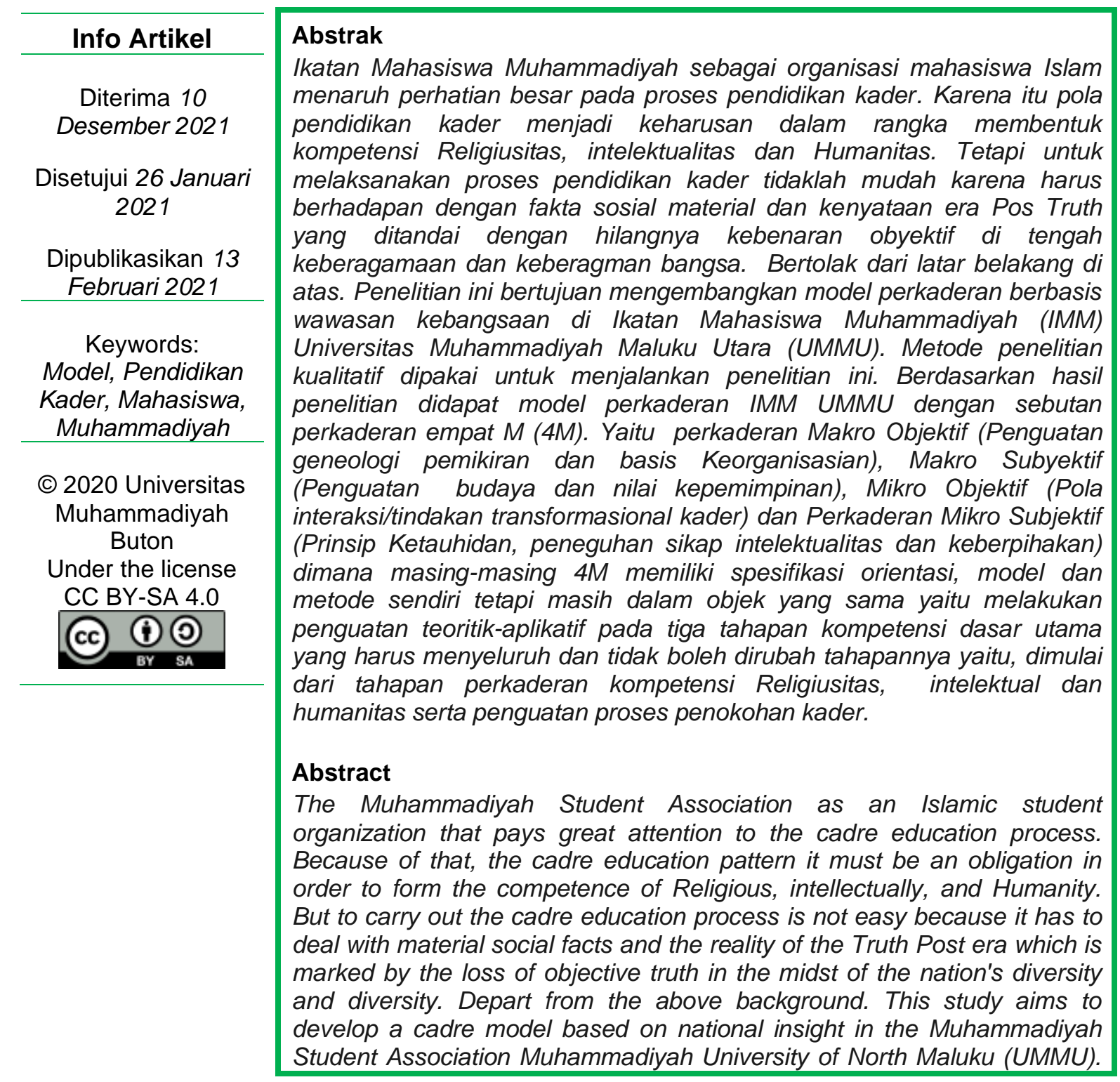




Qualitative research methods are used to carry out this research. Based
on the results of the study, the UMMU IMM cadre model was called the
four M (4M) cadre. Namely, the objective Macro cadre (Strengthening the
genealogy of thought and organizational basis), Subjective Macro
(Strengthening culture and leadership values), Micro Objective (Cadre's
pattern of interaction / transformational action) and Subjective Micro
Cadres (Principles of Obedience, strengthening of intellectual attitudes and
partisanship) where each $4 M$ has a specific orientation, The model and
method itself are still in the same object, namely to strengthen the
theoretical-applicable aspects of the three main basic competency stages
which must be comprehensive and the stages should not be changed,
namely, starting from the cadre stages of Religious, intellectually, and
Humanity competence as well as strengthening the process of
characterizing cadres.

\section{Pendahuluan}

Pendidikan (Perkaderan) Islam bukan sekedar proses penanaman nilai-nilai moral untuk membentengi diri dari ekses negatif globalisasi. Tetapi yang paling urgen adalah bagaimana nilai-nilai moral yang telah ditanamkan pendidikan Islam tersebut mampu berperan sebagai kekuatan pembebas (liberating force) dari himpitan kemiskinan, kebodohan, keterbelakangan sosial budaya dan ekonomi (Syafi'i Ma'arif). Selama ini pendidikan Islam masih cenderung dikotomis, terpisah secara diametral, yakni pendidikan yang hanya menekankan dimensi transendensi tanpa memberi ruang pada aspek humanisasi dan liberasi dan atau sebaliknya pendidikan Islam yang hanya menekankan dimensi humanisasi dan liberasi dengan mengabaikan aspek transendensi. Dalam teori sosialnya Kuntowijoyo (alm) dikenal dengan IImu Sosial Profetik (Isnanto, 2017).

Sebab itu Ikatan Mahasiswa Muhammadiyah (IMM) melaksanakan pendidikan untuk membentuk kader Ummat, kader Bangsa dan kader Persyarikatan dengan penguatan pada tiga kompetensi dasar utama sekaligus yaitu kompetensi Intelektualitas, humanitas dan religiusitas (Rajiah \& Rusydi, 2016). Sementara kader di IMM adalah kelompok inti organisasi yang menggerakan organisasi untuk sampai pada tujuannya "Menjadi Akademisi Muslim yang berakhlak Mulia demi Tercapainya Cita-Cita Muhammadiyah yaitu Masyarakat Islam yang Sebenar-Benarnya". Karena itu IMM mengembangkan pola perkaderan atau proses pendidikan bagi kader-kadernya. Disusun dalam buku pedoman perkaderan yang disbut dengan Sistem Perkaderan Ikatan (SPI).

Dalam proses perkaderan IMM membawa misi gerakan Muhammadiyah sebagai gerakan Islam berkemajuan. Ketua Umum PP Muhammadiyah Haedar Nashir, Islam Berkemajuan merupakan gagasan keagamaan yang mengedepankan praksis humanisme universal.

Salah satu kontekstualisasi terpenting dari gagasan fundamental Islam Berkemajuan yang diupayakan Muhammadiyah adalah Dar al-'Ahd wa alShahadah. Artinya, Indonesia yang sebenarnya merupakan Negara Pancasila, dipandang sebagai negara perjanjian (dar al-'ahd) dan persaksian (al-shahadah). Hal itu bertujuan untuk memberikan pedoman bagi para aktivis Muhammadiyah mengenai hubungan negara dan persyarikatan, sebagai fondasi pertahanan ideologis, sebagai alat harmonisasi politik, dan manifestasi intelektual dan politik yang menekankan pentingnya nasionalisme kebangsaan (Hasnan, 2010). 
Berdasarkan keputusan Muktamar Muhammadiyah ke-47 di Makassar tahun 2015, Muhammadiyah memandang bahwa Negara Kesatuan Republik Indonesia (NKRI) adalah Negara Pancasila yang ditegakkan di atas falsafah kebangsaan yang luhur dan sejalan dengan ajaran Islam. Pemahaman Muhammadiyah mengenai bentuk negara Pancasila merupakan hasil pemahaman penafsiran atas ayat al-Qur'an surat Saba' ayat 15, "baldatun thayyibatun wa rabbun ghafur", yaitu suatu negeri yang baik dan berada dalam ampunan Allah (Romadlan, 2020)

Karena itu sebagai organisasi otonom Muhammadiyah. konsepsi islam berkemajuan sebagai gerakan humanisme dan kebangsaan menjadi pedoman sekaligus spirit bagi Ikatan Mahasiswa Muhammadiyah dalam melaksanakan kaderisasi pada ranah kemahasiswaan, kemasyarakatan dan keislaman dalam konteks kebangsaan menjadi sangat penting dan terdesak mengingat berbagai krisis kebangsaan terus menerus mewarnai perjalanan bangsa ini.

Sebagai organisasi yang memiliki kepengurusan nasional dan tersebar hampir di semua kampus. Ikatan Mahasiswa Muhammadiyah (IMM) diharapkan mewarnai dan melahirkan generasi baru di jamannya sebagai kekuatan moral dan asset pemersatu bangsa. Bukan sebaliknya turut menjadi aktor bagi perpecahan di tengah persoalan bangsa.

IMM mengemban misi transformasi kader, pada ranah ke-ummatan, kebangsaan dan persyarikatan (kader ummat, kader bangsa dan kader persyarikatan). Untuk melahirkan kader yang memiliki visi keumatan, kebangsaan dan persyarikatan. IMM tidak cukup hanya dengan pola perkaderan yang fokus pada ranah keumatan dan persyarikatan. Harus berkolaborasi dengan berbagai pihak dan dengan multi konsepsi untuk mencapai visi kebangsaan di tengah perubahan revolusi informasi dan komunikasi yang sedemikian cepat. Sehingga kader-kader Ikatan Mahasiswa Muhammadiyah tidak justeru menjadi agen-agen hoax dan berita bohong di tengah keanekaragaman suku, agama, ras dan adat istiadat.

Kenapa demikian, karena hampir dalam kurun waktu lima tahun ini bangsa disuguhi oleh dagelan politik berwajah kuasa simbol keagamaan dalam arena politik nasional, daerah dan di media sosial yang juga akhirnya menyita perhatian para mahasiswa berlatar organisasi keagamaan untuk terlibat atau melibatkan diri dalam diskursus ilmiah sampai masalah remeh-temeh di media sosial seperti fenomena share dan commen. Dimana, baru membaca judul langsung memberikan commen dengan diksi-diksi yang "menyerang" dan merasa lebih benar. Begitupun ketika ada judul yang mewakili emosi keagamaan dan eksistensinya. Tanpa harus membaca, langsung bagikan disertai keterangan yang seringkali memanas-manasi. Bahkan, dimungkinkan menyebarluaskan ketidak sukaan dalam bentuk editan-editan foto di media sosial. Yang berarti, berkecenderungan pada ketidakmampuan dalam merawat keragaman karena faktor subyektinya.

Inilah era Pos Truth. Didefenisikan kamus Oxford sebagai kondisi dimana fakta tidak terlalu berpengaruh dalam membentuk opini public dibanding emosi dan keyakinan personal. Dalam situasi tersebut, informasi hoax punya pengaruh yang jauh lebih besar ketimbang fakta yang sebenarnya. Dalam penjelasan kamus Oxford. Istilah pos truth pertamakali digunakan pada tahun 1992. Adalah steve Tesich yang menggunakan istlah pos-truth dimajalah The Nation ketika 
merefleksikan kasus perang teluk dan kasus iran yang terjadi di periode tersebut (Hartono, 2018).

Di era Post-trust (Pasca Kebenaran) terjadi dominasi kebenaran personal. Dan abai pada kebenaran yang datang dari arah yang berbeda dari dirinya. Perbedaan pandangan apalagi dalam pilihan politik. Dianggap sebagai musuh yang harus disingkirkan. Sehingga narasi yang digunakan dalam politik. Juga narasi yang dangkal. Sebab mengutamakan subyektifitas dirinya tanpa memfilter pendapat yang berbeda. Dan memang begitulah yang nampak akhir-akhir ini, terlihat semakin merebaknya radikalisme politik identitas yang akut. Masingmasing pihak tampil dengan identitas ke "AKU"annya yang paling benar dan menganggap kelompok yang lainnya sebagai pihak yang selalu salah (Fatah, 2019).

Keanekaragaman yang dulu terjalin kokoh dan kuat dalam bingkai kebangsaan Indonesia, kini terasa semakin longgar dan rentan terhadap masuknya pengaruh nilai-nilai universal yang tidak sesuai dengan nilai-nilai dan norma-norma yang berlaku di Indonesia merupakan dampak dari perubahan yang tidak dapat terhindari. Wawasan kebangsaan tumbuh sebagai identitas diri dari proses sejarah dan juga pola budaya yang bersifat majemuk dan beraneka ragam, tetapi tetap dalam kesatuan. Pembentukan jiwa patriotik, cinta tanah air dan rela berkorban merupakan kewajiban bagi setiap warga negara (Kusmayadi, 2017).

Berdasarkan hasil diskusi Direktorat Politik, komunikasi dan Informasi Bapenas tentang wawasan kebangsaan. Oto Hadi menggunakan teori Sistem AGIL Talcoot Parsons dalam pengembangan pola pikir wawasan kebangsaan sebagaimana tersebut pada gambar berikut:

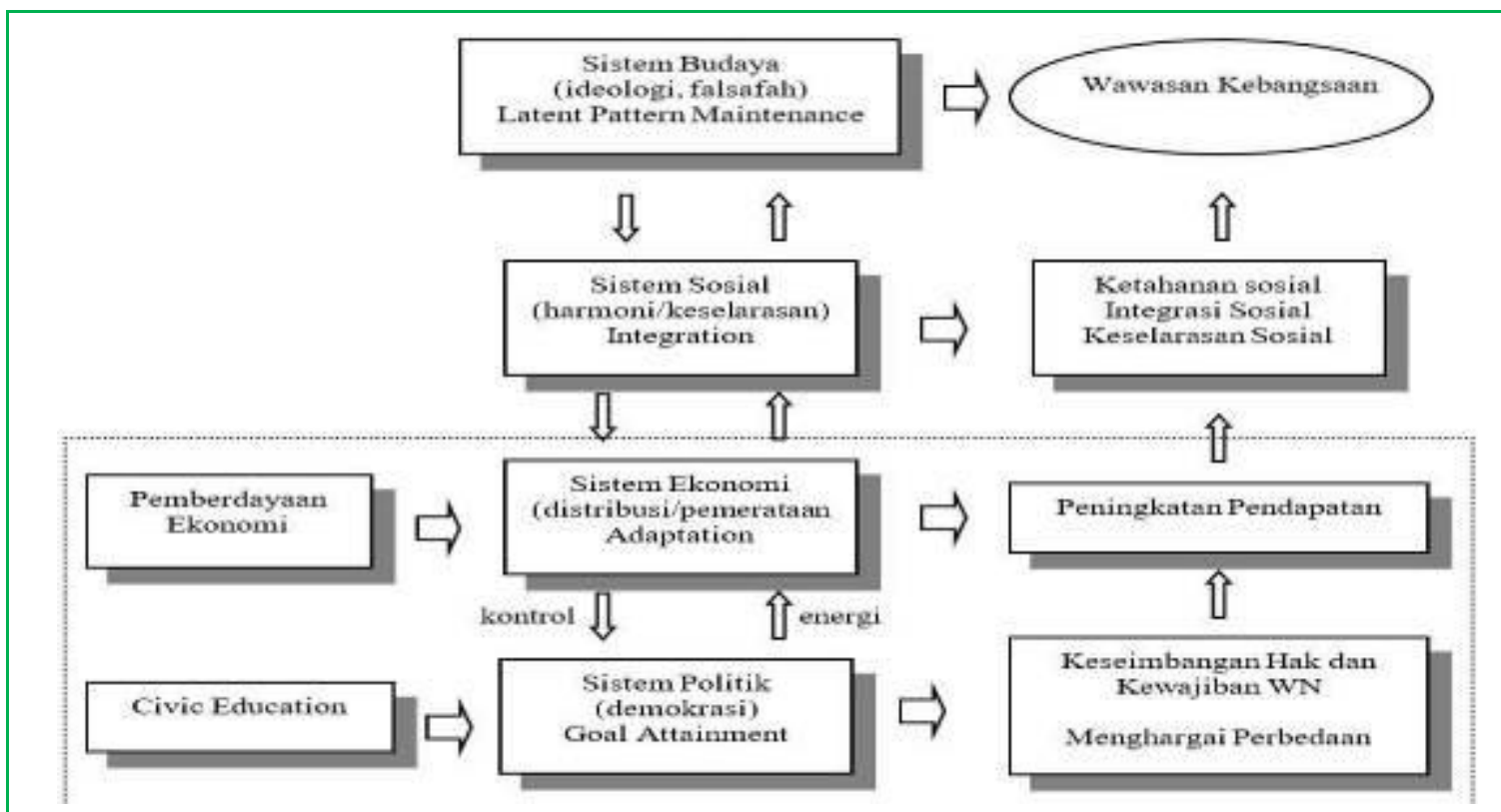

Gambar 1: Pola Pikir Pemahaman Wawasan kebangsaan (Hadi, 2019).

Gambar 1 tersebut di atas menggambarkan model pengembangan wawasan kebangsaan dimulai dengan Laten Pattern Maintenance T. Parsons sebagai sub system budaya. Yang meliputi; (ideologi dan falsafah), Integrasi sebagai sub system sosial (harmoni/kesalarasan), adaptasi sebagai sub system 
ekonomi (distribusi/pemerataan) dan Goal Attainment (system politik/Demokrasi) sebagai tujuan pengambangan hak Hak dan kewajiban Warga negara dan menghargai perbedaan di tengah kebinekaan Bangsa Indonesia.

Dengan demikian maka pola perkaderan IMM berbasis wawasan kebangsaan di era post-Trust ini menjadi urgen untuk dilaksanakan. Makhrus and Aminudin (2014) dalam bukunya "Geneologi kaum merah; pemikiran dan gerakan". Mengungkapkan bahwa fase Gen pemikiran Ikatan mahasiswa Muhammadiyah terdiri atas tiga fase. Pertama, fase internalisasi yang disebutnya sebagai gen induk dan gen tambahan. Gen induk yaitu keislaman, kemuhammadiyahan, ke-IMMan dan gerakan Mahasiswa. Sementara tambahannya adalah filsafat (IImu dan Wujud), analisis kelas, Gerakan Sosial baru, IImu sosial Profetik, NGO dan ekonomi politik. Sementara fase kedua adalah fase motorik, yang disebutnya fase implementasi. Yaitu berupa Advokasi; terdiri dari (menolak politisi busuk, tolak aktivis gadungan, tolak korporatokrasi, tolak militerisme dan tolak komersialisasi pendidikan) serta Gerakan Kota dan Desa. Yaitu perlindungan terhadap kaum miskin kota (anak jalanan, gepeng), perlindungan terhadap petani, buruh, nelayan dll serta aliansi taktis strategis;(UU, PP, Perda, Perdes). Dan fase ketiga, disebutnya fase karakter IMM sebagai output yaitu pertama, ciri dari Ideologi Gerakan terdiri dari( Transendensi keimanan, anti penindasan dan keberpihakan terhadap kaum tertindas, anti sosialisme, kapitalisme, komunisme dan liberalisme) dan kedua, Kemampuan( Paham konsep sampai praktis, Analisa tajam, satu paradigma, diaspora kader pda sektor strategis dan kepemimpinan nasional).

Penelitian yang dilakukan oleh Muflihah (2017) dengan judul "perkaderan Intelektual Pimpinan Cabang Ikatan Mahasiswa Muhammadiyah Sukuharjo mengungkapkan bahwa perkaderan intelektual yang diterapkan dalam PC IMM Kabupaten Sukoharjo ada dua jenis yaitu perkaderan intelektual utama dan pendukung. Perkaderan intelektual utama dalam bentuk kegiatan Baret Merah (BM) dan Sukoharjo Intelektual School (SI School), sedangkan perkaderan intelektual pendukung dilaksanakan dalam bentuk diskusi. Metode yang diterapkan dalam perkaderan intelektual ada tiga yaitu Focus Group Discussion (FGD), presentasi, dan penugasan. Muflihah menemukan bahwa pelaksanaan perkaderan intelektual memiliki faktor pendukung dan faktor penghambat. Faktor pendukung ada yang dari dalam tubuh PC IMM Kabupaten Sukoharjo, antara lain: (1) Orientasi gerakan didirikanya IMM Sukoharjo diarahakan ke intelektual; (2) Kondisi PC IMM Sukoharjo yang memiliki visi misi keilmuan dan kebiasaan diskusi. Faktor dari luar tubuh PC IMM Kabupaten Sukoharjo adanya dukungan dari demisioner lembaga atau instansi Muhammadiyah. Faktor penghambat perkaderan intelektual PC IMM Kabupaten Sukoharjo: (1) Dari segi pelaksana kurang konsistennya panitia terhadap jobdisk yang menjadi amanahnya, sehingga mempengaruhi konsep yang sudah disusun rapi kurang terlaksana dengan baik; (2) Masih ada pimpinan ataupun kader yang kurang minat dalam bidang keilmuan, sehingga target semua pimpinan dan kader menguasai keilmuan dengan baik belum sepenuhnya terlaksana; (3) Kendala keuangan menjadi hal yang belum terpecahkan, kerena PC IMM Kabupaten Sukoharjo masih sangat tergantung dengan bantuan dari pihak pihak lain

Karena itulah penelitian tentang model perkaderan IMM berbasis wawasan kebangsaan di Universitas Muhammadiyah Maluku Utara dipandang perlu 
sebagai upaya menyiapkan generasi yang memiliki pemikiran terbuka dan menyadari sepenuhnya kebinekaan indonesia sebagi mozaik terindah yang patut dijaga dan dipelihara dengan baik. Selain itu, sejatinya keberadaan perguruan tinggi muhammadiyah adalah aset organisasi bagi pengembangan sumberdaya manusia dan wujud konkret pengkhidmatan muhammadiyah dalam rangka mencerdaskan kehidupan umat, bangsa dan negara.

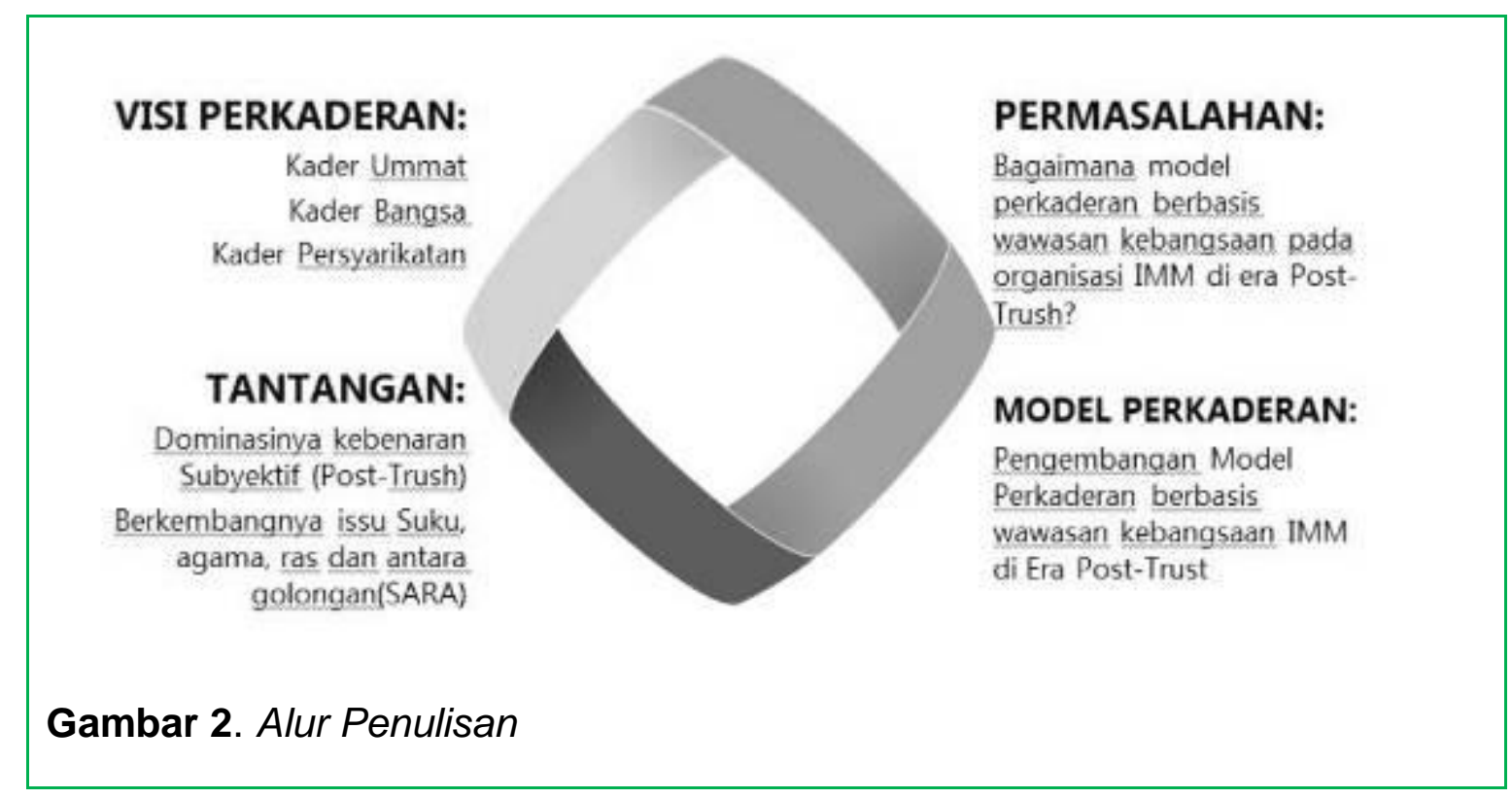

Gambar 2 tersebut di atas. Memperjelas bahwa penelitian ini, sangat penting dan urgen untuk pengembangan model perkaderan berbasis penguatan wawasan kebangsaan di Organisasi Ikatan Mahasiswa Muhammadiyah Universitas Muhammadiyah Maluku Utara. di tengah dominasinya kebenaran subyektif (Era Post-Truth). Yang ditandai oleh berita bohong, hoax dan isu SARA yang dapat mengancam persatuan dan kesatuan bangsa. Karena itu riset ini berupaya menjawab pertanyaan penelitian tentang bagaimana Model pengembangan perkaderan berbasis Wawasan Kebangsaan di Ikatan Mahasiswa Muhammadiyah Universitas Muhammadiyah Maluku Utara di Era Pos-Truth?

\section{Metode Penelitian}

Penelitian ini merupakan penelitian kualitatif dengan menggunakan pendekatan deskriptif. Bertujuan untuk mengumpulkan dan menguraikan data secara menyeluruh serta diteliti sesuai dengan pokok persoalan. Yang menjadi subyek penelitian adalah orang-orang (kader IMM) yang berhubungan langsung dalam memberikan informasi tentang situasi dan kondisi lokasi atau obyek penelitian. Yaitu kader IMM yang tersebar pada delapan fakultas (komisariat) di Universitas Muhammadiyah Maluku Utara.

Sementara Objek penelitian ini adalah pengkaderan IMM Koordinator Komisariat Universitas Muhammadiyah Maluku Utara. Metode pengumpulan data antara lain observasi, FGD, wawancara dan dokumentasi. Adapun teknik yang digunakan dalam penelitian ini adalah analisis deskriptif kualitatif. Yaitu dengan melakukan pengamatan secara menyeluruh pada saat observasi, FGD, wawancara dan dokumentasi yang diproses melalui pencatatan-pencatatan 
ataupun rekaman kemudian disusun atau diklasifikasi dan dikoding secara tematik berdasarkan permasalahan penelitian.

\section{Hasil dan Pembahasan}

Berdasarkan hasil interview dan Fokus Group Discusion (FGD) didapati delapan kategori dari beragam tema atau permasalahan yang terjadi di Ikatan Mahasiswa Muhammadiyah (IMM) Universitas Muhammadiyah Maluku Utara. Yaitu persoalan kader bangsa, kader umat, Kader Persyarikatan, Post-Trust dan tantangan perkaderan, serta permasalahan intelektualitas, humanitas, religiusitas dan persoalan pola perkaderan IMM di UMMU. Sebagaimana tersebut di dalam gambar 3 berikut:

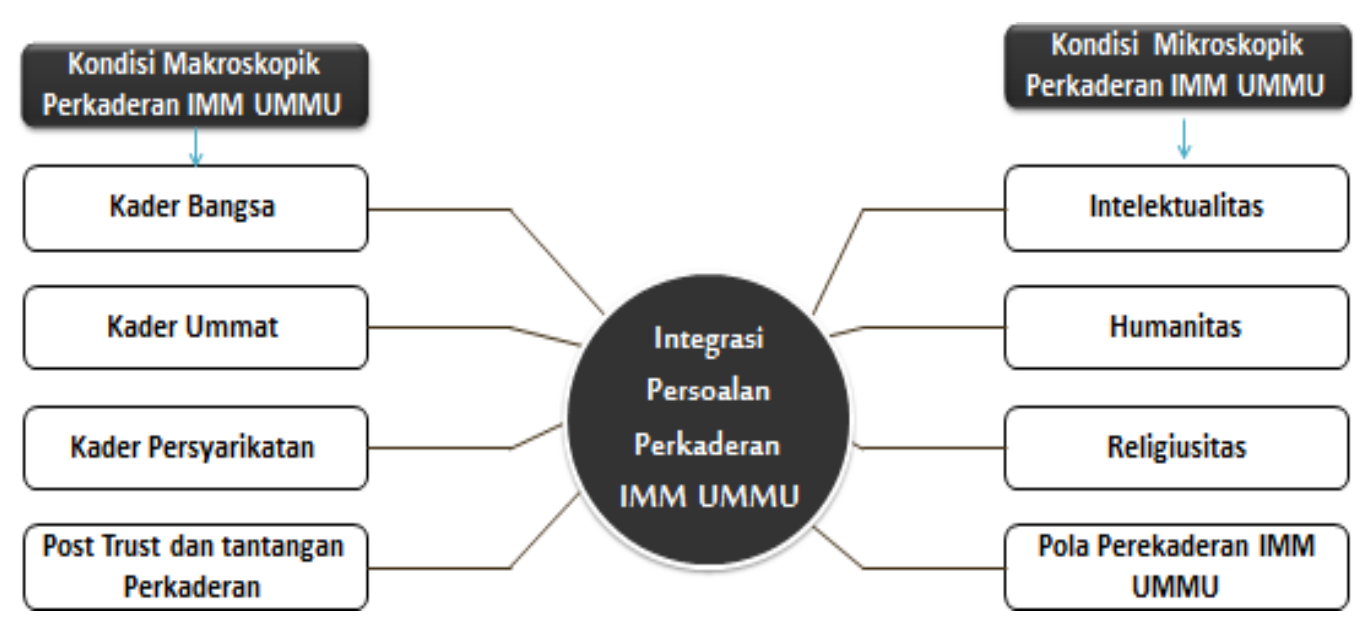

Gambar 3. Delapan persoalan perkaderan IMM UMMU

Delapan tema persoalan perkaderan dapat dibagi menjadi tiga tahapan realitas dinamika perkaderan :

1. Persoalan makro objektif yaitu kondisi eksternal yang dapat mempengaruhi skeligus menjadi tantangan IMM UMMU dalam mencapai tujuan perkaderannya. Yaitu, [a] Permasalahan kader Bangsa, Kader Ummat dan Kader Persyariakatan, [b] Post-Trust dan tantangan Perkaderan.

2. Persoalan makro subyektif. Yaitu nilai perkaderan berupa trikompetensi yakni Intelektualitas, humanitas dan Religiusitas.

3. Persoalan Mikro Obyektif dan subyektif berupa tindakan kader dan Persoalan pola perkaderan IMM UMMU.

\subsection{Persoalan Makro Obyektif}

Makro obyektif adalah persoalan eksternal yang mempengaruhi sekaligus menjadi tantangan perkaderan IMM UMMU dalam mentransformasi kaderkadernya untuk menjadi kader bangsa, kader Ummat dan kader persyarikatan dan situasi Post-Trust Sebagaimana pada tabel 1 berikut:

Tabel 1.: Persoalan Perkaderan Makro Obyektif IMM UMMU

$\begin{array}{llll}\text { Makro Objektif } & \text { Makro Objektif } & \text { Makro Objektif Kader } & \text { situasi Post-Trust } \\ \text { Kader Bangsa } & \text { Kader Ummat } & \text { Persyarikatan } & \end{array}$


Pancasila, Intoleransi, Media Sosial, Kerukunan antar umat beragama, Solidaritas kebangsaan, tanggung jawab sosial kader, persoalan isu SARA dan politik kekuasaan serta persoalan basis ekonomi umat.

\author{
Sikap beragama \\ yang tertutup, \\ persoalan \\ keberagaman, \\ media sosial, \\ menguatnya \\ materialisme \\ individual persoalan \\ isu SARA dan politik \\ kekuasaan serta \\ persoalan basis \\ ekonomi ummat
}

\author{
Eksploitasi isu \\ sara, berita \\ bohong dan \\ sebaran \\ kebencian di \\ medsos, seberan \\ kebencian atas \\ dasar agama, \\ informasi hoax di \\ telan mentah- \\ mentah, ekstrim \\ menggapi isu-isu \\ di medsos, \\ pikiran yang \\ tertutup dan \\ merasa paling \\ benar dll.
}

Tabel 1 tersebut di atas adalah sebaran tema yang dibicarakan sepanjang Interview dan FGD tentang model pengembangan perkaderan IMM UMMU berbasis wawasan kebangsaan. Bahwa tantangan untuk menjadi kader bangsa, Kader Ummat dan kader persyarikatan tidaklah mudah karena harus berhadapan dengan kenyataan bahwa di kalangan muda khususnya dan masyarakat pada umumnya juga masi didapati sikap intoleransi dimana persoalan isu suku, agama, ras dan antar golongan (SARA) masih mengemuka terutama pada saat pemilihan kepala daerah atau pemilihan presiden.

Bahwa seringkali seperti yang sekarang mulai terjadi di media sosial jelang pemilihan kepala daerah, politik identitas mulai Nampak, akun-akun palsu tumbuh bagai jamur, hadir menebar kebencian. Di ruang ini toleransi terhadap Suku, agama bahkan jenis kelamin tidak mendapat tempat untuk diapresiasi. Semua hadir untuk memaksa orang mengikuti keinginannya. Semua ini menurut saya karena ketika kita memasuki babak baru kehidupan berbangsa yang disebut ordebaru, semua ekspresi keyakinan dan berbagai ideology hadir dan berlomba menunjukan eksistensinya sementara basis ideology atau falsafah hidup kita dalam berbangsa belum terlalu baik. Yaitu pancasila. Sehingga kemudian pancasila ini hanya sebagai simbol saja. (Wawancara, 22/7/2020. Kader IMM Fak.Ekonomi-a)

Bicara tentang pancasila dikalangan pemuda terutama mahasiswa kita bisa hitung dengan jari. Kenyataannya kita juga jarang membahasnya. Menurut saya ini fenomena umum, dimana pancasila hanya sebagai simbol bahwa kita punya falsafah berbangsa tetapi sejauh mana falsafah itu dapat menjadi pandangan hidup dan citacita kehidupan sosial, itu yang belum Nampak yang Nampak justeru ideologi kapitalisme dan ideologi transnasional (Kader Fisip UMMU-a, wawancara, 22 Juli 2020).

\section{Ketua Koordinator Komisariat IMM UMMU mengatakan bahwa:}

Perbincangan tentang relasi kebangsaan, keumatan dan persyarikatan di Muhammadiyah telah ada Konsep Dar al-'Ahd wa al-Shahadah (negara perjanjian dan persaksian) yang dijadikan Muhammadiyah sebagai pedoman dan dasar ideologi dalam transformasi kebangsaan dan keindonesiaan bagi semua elemen persyarikatan. Termasuk di dalamnya Perguruan tinggi Muhammadiyah (PTM) maupun organisasi otonomnya, seperti Ikatan Mahasiswa Muhammadiyah (IMM) di Universitas Muhammadiyah Maluku Utara UMMU) karena itu bagi IMM. Tidak ada pertentangan antara relasi agama dan Negara, kecuali relasi yang saling 
menguntungkan dalam hal perbaikan. Jadi soal pancasila itu suda selesai. Tugas kita sekarang mengisinya dengan kebaikan untuk semua. (Wawancara, 29/8/2020).

Karena itu menurut (Kader IMM Komisariat Ekonomi-a) bahwa gagasan Dar al-'Ahd wa al-Shahadah:

Harus dijadikan sebagai dasar, orientasi pemikiran dan tindakan bagi seluruh anggota Muhammadiyah. Terutama IMM di UMMU dalam konteks pembangunan bangsa dan negara agar tidak ada lagi pertentangan atau pemahaman yang keliru soal hubungan Negara dan agama terutama islam dan hubungan Negara dan muhammadiyah itu sendiri. (Wawancara, 29/8/2020).

Hasnan Bahtiar (2019), seorang tokoh CMM (Cendekiawan Muda Muhammadiyah) Universitas Muhammadiyah Malang (UMM). Mengatakan

Muhammadiyah secara khusus berupaya meredam laju gerakan Islamisme di Indonesia, dengan mengampanyekan gagasan alternatif, yakni Negara Pancasila sebagai Dar al-'Ahd wa al-Shahadah (negara perjanjian dan persaksian). Akan tetapi, dalam tataran implementatif, Muhammadiyah harus menghadapi tantangan-tantangan yang tidak mudah, seperti misalnya adanya sebagian kecil aktivis Muhammadiyah sendiri yang cenderung konservatif, adanya faktor eksternal yang memungkinkan infiltrasi ideologis sehingga menyebabkan pemisahan diri dan pengerasan sikap keberagamaan, dan adanya kontestasi politik praktis musiman yang melibatkan pelbagai instrumentalisasi agama untuk kepentingan politik kekuasaan (populisme Islamis)

\section{Fadila Nyongali (Kader IMM FIP) mengatakan bahwa:}

Memang Persoalan politik selalu menjadi sebab orang menebar kebencian atas nama agama, suku dan karena itu menjadi penyebab konflik di masyarakat. Sebab itu juga perlu dipahami bahwa pancasila adalah pilar bangsa yang menjadi landasan sekaligus tujuan hidup berbangsa dan bernegara. Karena itu menurut saya Landasan perkaderan untuk melahirkan kader umat, kader bangsa dan kader persyarikatan harus dipupuk dan dikembangkan dengan baik melalui kajian-kajian internal terhadap ke tiga poin tersebut. Dengan selalu apdate persoalan kebangsaan, melihat dan membekali persoalan pancasila dan lain-lain yang berhubungan persatuan dalam kebinekaan. IMM UMMU menurut saya harus lebih giat dalam mengembangkan kajian- kajian dan agenda-agenda kebangsaan dan keumatan. Terlebih tentang IMM. Baik yang sifatnya internal maupun yang sifatnya eksternal. Karena selama ini belum aktif atau tidak berjalan. (Wawancara, 27/8/2020).

\section{Fitriyani Ashar (Kader IMM Faperta) mengatakan}

Bahwa untuk membentuk kader umat, bangsa dan persyarikatan perlu dikembangkan sikap solidaritas. Bahwa kader bangsa itu, kader yang memiliki wawasan yang luas dan berfikir tentang IMM lebih jauh bukan hanya sekedar internal tetapi juga eksternal. Seperti persoalan kebangsaan maupun persoalan- persoalan lokal dan internasional. Begitupula kita harus memahami makna kebinekaan adalah berbeda-beda tetapi tetap satu sebagai sebuah bangsa. Dimana kita harus menjaga perbedaan itu dengan tidak menebar kebencian antar sesama dan menyebar berita bohong atau hoax di tengah persoalan bangsa yang tidak kunjung selesai ini. (Wawancara, 27/8/2020).

\section{Lisda Amun (Kader IMM Fikes UMMU) mengatakan}

Untuk melahirkan kader bangsa, umat dan persyarikatan. Perlu dilakukan evaluasi internal untuk menambah wawasan kebangsaan. Kader bangsa adalah kader yang bertanggung jawab, cintah tanah air dan memegang sikap bahwa kita hidup dalam perbedaan tetapi harus tetap satu dalam kebinekaan itu. (Wawancara, 27/8/2020)

Ivan Wailoa (Kader IMM FAI UMMU) mengatakan bahwa "kader bangsa menurut saya adalah yang banyak berfikir, bertindak demi kemajuan indonesia. Dengan tetap dalam ikatan kebangsaan. Bahwa kita berbeda tetapi satu dan kita 
harus menerima perbedaan itu". (Wawancara, 27/8/2020). Sementara Fadila Nyongali(Kader IMM FIP UMMU) berpendapat bahwa:

\begin{abstract}
"Kader bangsa itu menurut saya adalah orang yang mampu melihat persoalan bangsanya dan berupaya menyelesaikan atau memberi solusi persoalan itu. Dan secara personal Untuk melahirkan kader umat, bangsa dan persyarikatan pada diri sendiri, menurut saya harusnya kita asah dulu kecintaan kita pada bangsa agar kita dapat merespon persoalan bangsa ini secara total. Tidak setengah-tengah". (Wawancara, 27/8/2020).
\end{abstract}

Secara spesifik kader-kader IMM di Universitas Muhammadiyah Maluku utara memberikan ciri bagi kader bangsa, kader umat dan kader persyarikatan sebagaimana disebutkan pada gambar 5 berikut:

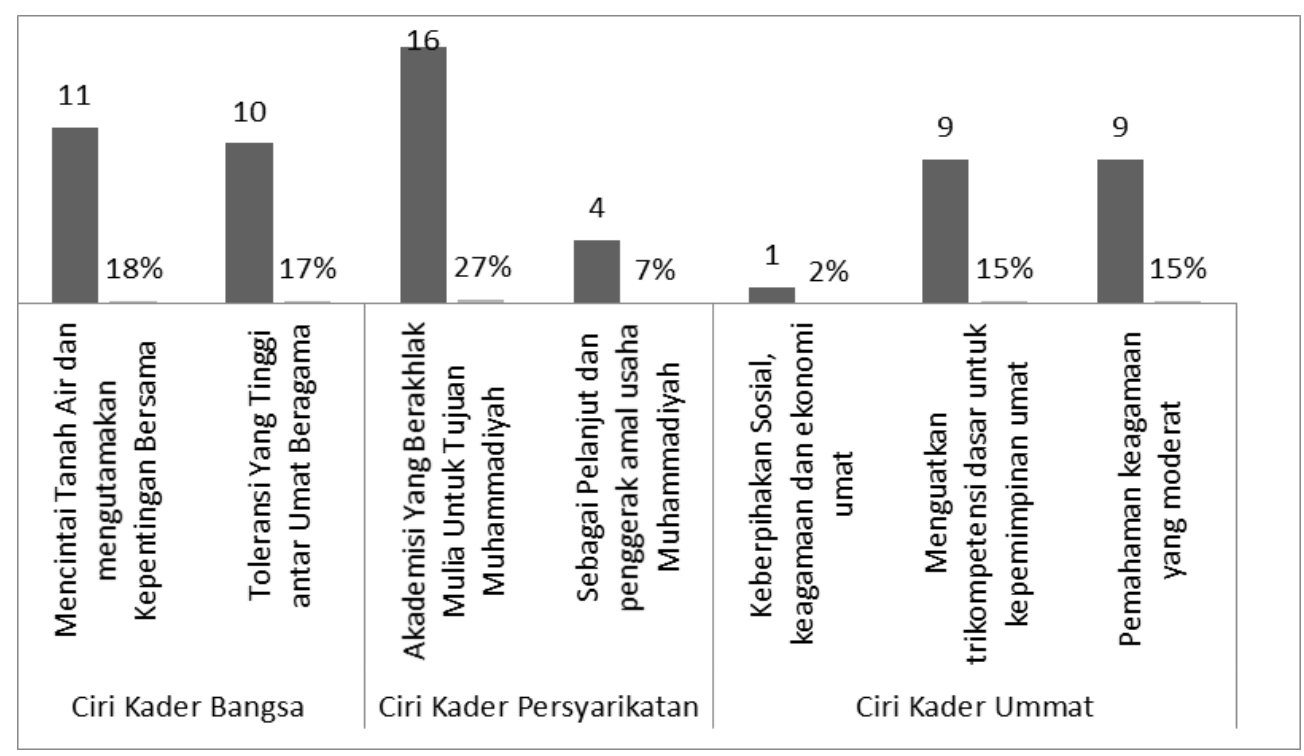

Gambar 5. Ciri Kader Bangsa, kader Persyarikatan dan Kader Ummat IMM UMMU

Gambar 5 tersebut di atas dapat dibaca bahwa mencintai tanah air dan mengutamakan kepentingan bersama berada pada posisi pertama dengan $18 \%$ dari 11 responden dan toleransi yang tinggi antar umat beragama berada pada posisi kedua dengan 17\% dari 10 responden yang memberikan pendapat tentang ciri kader bangsa di Universitas Muhammadiyah Maluku Utara. Mencintai adalah awal dari semua performance kepribadian kita dalam berbangsa karena dengan mencinta akan menentukan cara bagaimana kita bersikap dan berperilaku dengan demikian setiap anak bangsa akan merelakan kepentingan personalnya demi kepentingan bangsanya. Sebab di jaman yang penuh bebas dan individual ini berpotensi menghilangkan kebangggaan anak bangsa dari bangsanya sendiri.

Tingginya pendapat tentang kader bangsa dengan menempatkan toleransi antar umat beragama sebagai poin penting yang dipilih para responden tentu memberikan harapan baru pada kita tentang situasi berbangsa di masa depan. Sebab problem mendasar kita-akhir ini adalah tentang sikap menerima perbedaan yang mulai langkah dinegeri ini.

Para responden juga berpendapat bahwa akademisi yang berakhlak mulia adalah ciri kader persyarikatan dalam rangka mencapai tujuan muhammadiyah. Yaitu menegakan dan menjunjung tinggi agama islam sehingga terwujud masyarakat islam yang sebenar-benarnya". Masyarakat islam yang sebenar- 
benarnya oleh Pimpinan Pusat Muhammadiyah ditafsirkan sebagai masyarakat tauhid yang moderat, teladan, terbuka dan toleran, solid dan peduli pada sesama.

Sebagai pelanjut dan penggerak amal usha Muhammadiyah diberikan oleh $7 \%$ responden. Bahwa sebagai bagian dari mahasiswa di perguruan tinggi Muhammadiyah(PTM). IMM wajib menjada nama baik PTM dengan senantiasa berlomba-lomba dalam kebaikan dengan senantiasa memproduksi prestasiprestasi terbaik. Baik yang bersifat intra kampus maupun yang sifanya ekstra kampus sehingga IMM juga turut menjadi bagian penting yang telah dan akan terus memberikan konstribusi positif pada PTM sebagai konsekunsi kecintaan pada persyarikatan Muhammadiyah.

Sementara keberpihakan sosial, agama dan ekonomi umat dicirikan sebagai kader umat. Bahwa situasi materialisme yang melanda seluruh dimensi kehidupan. Baik pada aspek sosial, agama dan aspek ekonomi umat tentunya menjadi keberihatinan tersendiri bagi IMM di UMMU sehingga solidaritas untuk mendorong kerahmatan yang membebaskan pada situasi keterbelakangan umat pada poin tersebut menjadi usaha bersama. Menimal dengan terus menyiapkan diri untuk "memproduksi" generasi baru. Sehingga secara idealitas dan meterial siap menghadapi tantangan keumatan ke depannya.

Untuk menghadapi berbagai tantangan keumatan tersebut. Responden berpandangan perlu melakukan penguatan terhadap trikompetensi dasar (Intelektualitas, humanitas dan religiusitas) pada kader IMM sehingga tidak sekedar reaktif sesaat terhadap problem keumatan tetapi keberpihakannya bersifat keberlanjutan karena "matang" kapasitas intelektual dan kapasitas kerjakerja kemanusiaan yang dipadu oleh kapasitas keagamaannya yang toleran, berwawasan terbuka dan melihat jauh ke depan serta moderat yang oleh responden sebanyak $18 \%$ memberikan perlu adanya pemahaman dan sikap moderat di kalangan kader-kader IMM UMMU.

\subsection{Post-Trust dan tantangan Perkaderan}

Pos Truth adalah situasi eksternal yang mempengaruhi sekaligus menjadi tantangan perkaderan IMM UMMU karena di era ini menandai hilangnya kebenaran obyektif dan menguatnya emosi yang pada gilirannya memproduksi narasi kebencian karena, di era ini jugalah orang pandai menangkap dan mensiasati isu-isu sensitif Sebagaimana yang disampaikan kader-kader IMM UMMU dalam gambar beirkut: 


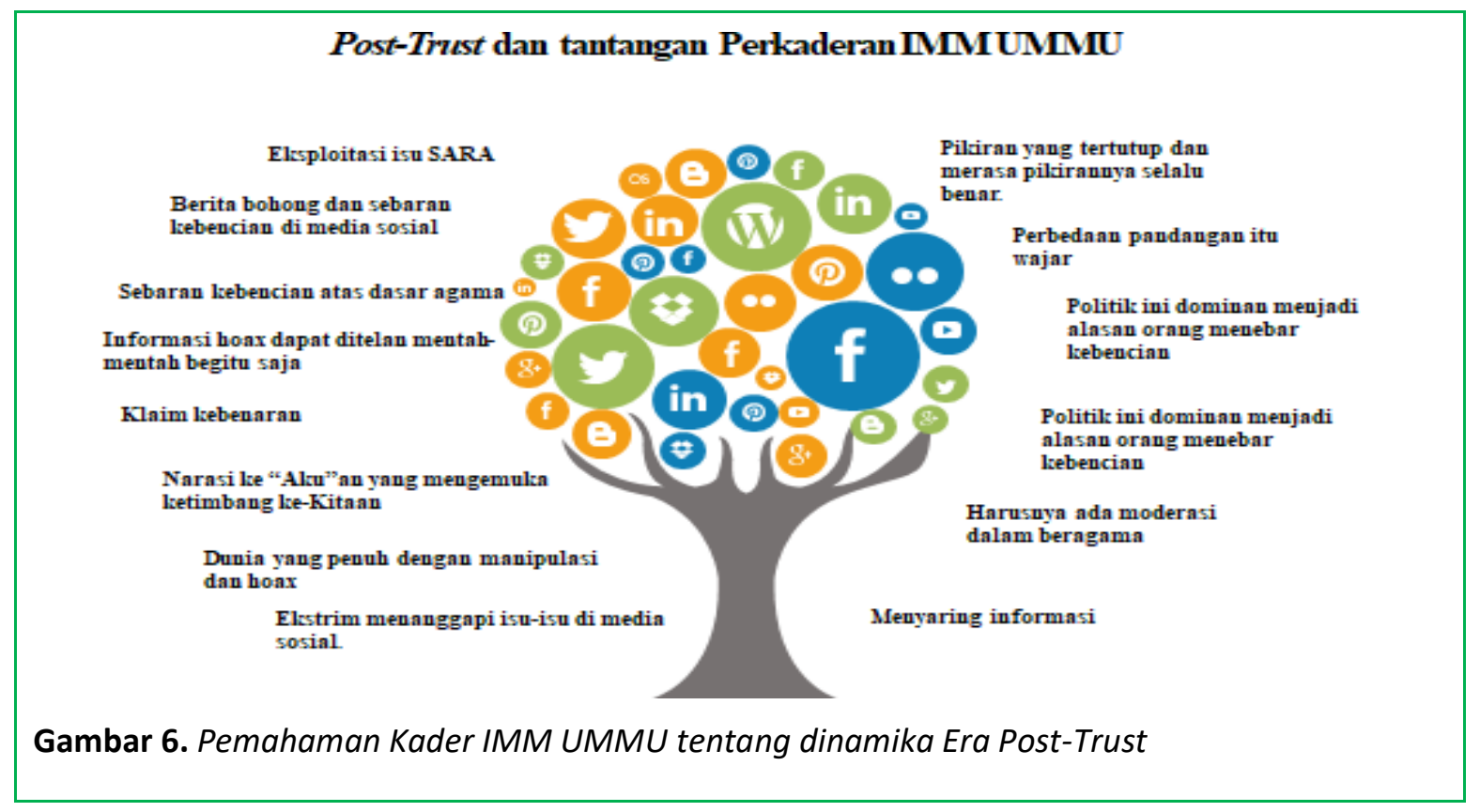

Gambar 6 di atas memperlihatkan pemahaman kader-kader IMM UMMU bahwa di era Post-Trust bukan saja terjadi klaim kebenaran secara subjektif yang mengemuka. Tetapi lebih dari itu, atas dasar pandangan subjektifnya. Seseorang bahkan dengan muda menebar kebencian atas dasar agama yang diyakininya sampai pada persoalan politik kekuasaan dimana isu suku, agama, ras dan antar golongan (SARA) digunakan sebagai alat legitimasi sekaligus alat untuk menebar kebencian.

Media sosial menjadi media utama dalam menyampaikan pandangan subyektif. Terutama pada isu-isu sensitif seperti simbol-simbol agama dan identitas dalam perhelatan politik. Karena itu cerdas bermedia dengan menyaring berbagai informasi di media social menjadi keharusan dewasa ini. Zulkarnain Pina (Ketua Cabang IMM Kota Ternate) mengatakan post-trust selalu ditandai dengan "pikiran yang tertutup dan merasa pikirannya selalu benar. Melalui sarana media sosial, Ekstrim menanggapi isu-isu di media sosial. Karena itu peran medsos perlu dibijaki dengan misalnya Membagi isu di medsos untuk di diskusikan dengan pikiran konstruktif(wawancara,27/8/2020).

Fadila Nyongali (Kader IMM Komisariat FIP UMMU) mengatakan, bukan saja soal klaim kebenaran dan pikiran yang tertutup tetapi soalan yang lebih besar adalah soal narasi kebencian antar sesama anak bangsa

Jika kita tidak benar-benar menyaring informasi sudah jelas akan menghasilkan konflik, karena ini menyangkut dengan beberapa hal termasuk suku, agama, ras serta gender. Karena kita sebagai anak bangsa sekarang berada dalam dunia yang penuh dengan manipulasi dan hoax. (Wawancara, 27/8/2020)

Karena itu, Fitriyani Ashar (Kader IMM Faperta UMMU) mengatakan:

Kita harus bisa memilih dan memilah berita atau menyaring informasi yang harus disebar. Karena jika salah, akan berdampak buruk bukan saja kepada kita tetapi seluruh masyarakat itu sendiri. Apalagi sekarang, hanya dengan Hanphone setiap orang bisa berselancar di medsos tanpa kontrol.

Ekklesia Hulahi (Kader IMM Komisariat FISIP UMMU) mengatakan” 
Seperti problem klaim kebenaran akan menjadi soal besar di kemedian hari. Karena yang muncul dipermukaan adalah narasi ke "Aku"an ketimbang ke- Kitaan" . karena itu Harusnya ada moderasi dalam beragama agar kader jauh dari fikiran dan tindakan intoleran apalagi melakukan kekerasan hanya karena berbeda keyakinan dan pandangan hidup (FGD, 27/8/2020).

\section{Fitriyani Ashar mengatakan:}

Di era post-trust ini, seringkali yang terjadi adalah eksploitasi isu SARA. Secara otomatis menghasilkan konflik dalam berbangsa. Apalagi sekarang ramai tersebar berita bohong dan sebaran kebencian di media sosial. Apalagi kalau suda berkaitan dengan persoalan agama. Maka kita harus berhati-hati. Sehingga menurut saya sebaran kebencian atas dasar agama tidak dibenarkan karena akan melahirkan konflik, karena dapat saja informasi hoax dapat ditelan mentah-mentah begitu saja. Kader IMM perlu memahami bahwa perbedaan pandangan itu wajar. Asal jangan sampai menimbulkan kebencian. Selain agama tentu juga sebab karena pilihan politik yang berbeda, dimana saya melihat politik ini dominan menjadi alasan orang menebar kebencian. Wawancara, 27/8/2020).

Secara spesifik. Kader IMM berpandangan era post-trust sebagaimana tersebut pada gambar 7 tersebut.

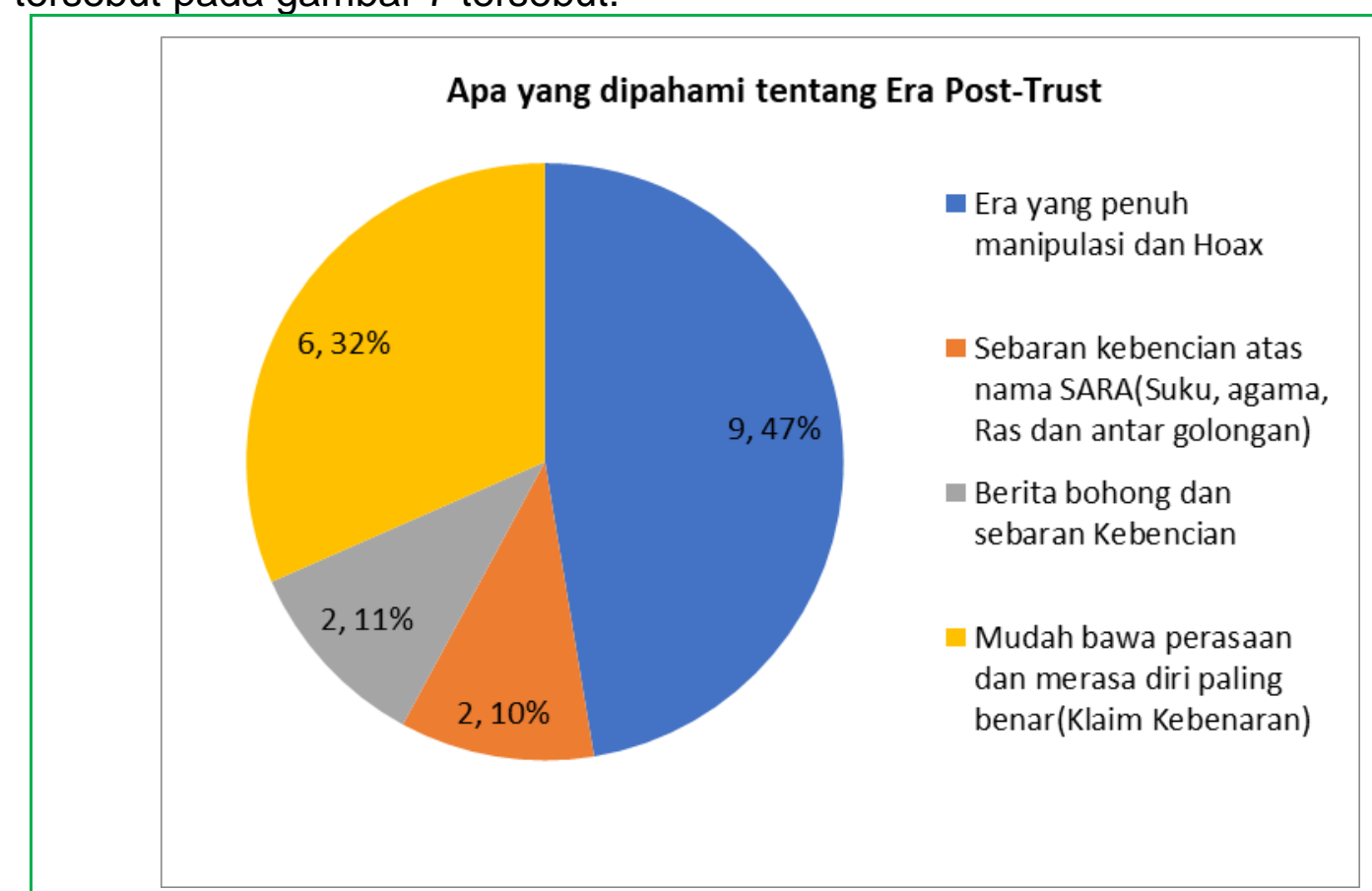

Gambar 7. Pandangan Kader IMM UMMU tentang Era Post Trust

Dari gambar tersebut dapat dibaca bahwa era post-trust atau pasca kebenaran adalah era yang penuh manipulasi dan hoax yang oleh responden sebanyak 47\% menempatkan pada posisi pertama dengan 9 responden. Pada posisi kedua sebanyak $32 \%$ atau 6 responden berpandangan bahwa era pos-trust adalah era dimana orang dengan mudah terbawa perasaan oleh situasi subyetifnya dan merasa paling benar atau klaim kebenaran atas sikap, pandangan dan keyakinan personalnya. Sementara era dimana berita bohong dan sebaran kebencian atas nama suku, agama, ras dan antar golongan samasama mendapat $11 \%$ dari masing-masing 2 responden dari pandangannya tentang post-Trust.

\subsection{Persoalan Makro Subyektif}


Persoalan Makro Subyektif adalah situasi atau persoalan perkaderan trikompetensi yaitu; Kompetensi Intelektualitas, Humanitas dan religiusitas kader IMM UMMU. Berikut lima belas (15) tema persoalan dari kategori trikompetensi IMM (Intelektualitas, humanitas dan Religiusitas) yang mengemuka selama melaksanakan penelitian:

Tabel 2. Lima Belas Persoalan Makro subyektif IMM UMMU

1 IMM UMMU masih lemah dalam silaturahim secara struktural dan kultural

$2 \quad$ Belum ada pola perkadearn yang sifatnya sistematis

3 IMM UMMU harus lebih giat dalam mengembangkan kajian-kajian dan agendaagenda kebangsaan

$4 \quad$ Penguatan kapasitas intelektual dan ideologi perlu terus dilakukan

5 IMM UMMU kaku menjawab isu nasional dan lokal. Serta menurunnya dialektika berfikir

6 Pasca Darul Arqam Dasar (DAD) tidak ada pendampingan

$7 \quad$ Referensi Kader IMM UMMU adalah Medsos

8 Ruh dari Muhammadiyah sudah hilang dari kader-kader IMM UMMU

$9 \quad$ IMM UMU harus lebih giat dalam mengembangkan kajian-kajian dan agendaagenda kebangsaan

10 Perlu melakukan penanaman dan pengembangan ideologi IMM yang kuat dalam sistem perkaderan

11 Humanitas itu harus mampu mengambil peran dalam ruang kemanusiaan

12 Bagaimana setelah kita sholat. Harus dirasakan manfaatnya di tengah masyarakat

13 IMM UMMU lebih mengedepankan Intelektualitas padahal harusnya yang dikuatkan adalah Religiusitas

14 Melaksanakan kajian-kajian keislaman di setiap komisariat

Harus sadar bahwa IMM adalaha mahasiswa yang religius yang harusnya memberikan tauladan bagi mahasiswa yang lain.

Berdasarkan hasil interview dan FGD terdapat lima belas item persoalan pengembangan trikompetensi pada IMM UMMU sebagaimana pada gambar di atas. Bahwa MM UMMU masih lemah secara structural dan kultural dalam pengembangan perkaderan kea arah penguatan trikompetensi dasar. Fadila Nyongali (Kader IMM FIP) mengatakan:

Kompetensi dasar intelektualitas, humanitas dan religiusitas ini menjadi dasar untuk pengembangan diri dan dasar dalam bergerak di ranah kebangsaan, keumatan dan persyarikatan. Dengan terus mengambil bagian atau berpartisipasi dalam tiga hal 
tersebut". Intelektualitas itu adalah upaya mengasah terus menerus pengetahuan yang bersifat umum maupun khusus. (Wawancara, 27/8/2020).

Namun persoalannya perkaderan untuk pengembangan kompetensi intelektual, humanitas dan religiusitas. Baik yang dilakukan secara struktural maupun kultural di internal IMM UMMU belum terkelola dengan baik. Fitriani Ashar (Kader IMM Pertanian) mengatakan:

\begin{abstract}
IMM UMMU masih Lemah dalam Silaturahim secara struktural dan kultural Karena tidak terkoordinasi oleh pimpinan dengan baik. Akhirnya selalu bermasalah, Tidak mengasah kader-kader secara intelektual. Karena itu belum ada pola perkaderan yang sifatnya sistematis. Baik secara structural maupun kultural. IMM UMMU harus lebih giat dalam mengembangkan kajian-kajian dan agenda-agenda kebangsaan. Dengan jalan mekukan penguatan pada trikompetensi dasar. Yaitu intelektualitas, humanitas dan Religiusitas, saya melihat Selama ini belum berjalan. Wawancara, 27/8/2020).
\end{abstract}

Isman Muges(Informan penelitian, Alumni Kader IMM Tehnik) “ Penguatan kapasitas Intelektual dan ideologi perlu terus dil akukan karena selama ini saya melihat IMM UMMU kaku menjawab isu nasional dan lokal, Menurunnya Dialektika berfikir, Kekurangan referensi dalam dialektika kebangsaan, Pasca DAD tidak ada pendampingan. Apakah kita harus diam. Ataukah kita harus bangkit?Kesadaran dan niat untuk perbaiki IMM. Misalnya kader-kader punya buku berapa? Referensi kader IMM UMMU adalah medsos. Begitupula sebagian kader Trikompetensi tidak mau belajar (FGD, 27/8/2020).

Begitupula Lisda Amun (Kader IMM Fikes) mengatakan bahwa:

IMM UMMU harus lebih giat dalam mengembangkan kajian-kajian dan agendaagenda kebangsaan, keumatan dan IMM Baik yang sifatnya internal maupun yang sifatnya eksternal. Karena selama ini pola perkaderan dalam mewujudkan kompetensi intelektualitas, humanitas dan religiusitas maupun menyiapkan sebagai kader umat, kader bangsa dan kader persyarikatan belum sistematis. (Wawancara, 27/8/2020).

Sementara dalam pengembangan basis humanitas kader Fadila Nyongali mengatakan:

Humanitas itu mampu mengambil peran dalam persoalan kemanusiaan. Pada intinya kita hidup saling membantu satu sama lain. Tetapi humanitas yang kita maksudkan harus meletakannya dalam bingkai religiusitas bukan pada kebebasan atau individualisme. Begitu pula Religiusitas itu persoalan agama. Namun tidak terbatas hanya pada sholat. Karena persoalan ibadah ini bersifat luas yakni tentang bagaimana setelah kita shalat, keberadaan kita dapat dirasakan manfaatnya di tengah masyarakat. (Wawancara, 27/8/2020).

M. Gadri Sanaba (Kader IMM FAI) sebagai upaya untuk menyiapkan kader umat, kader bangsa dan kader persyarikayan. Maka perlu melakukan pengembangan dan penanaman ideologi IMM yang kuat dalam sistem perkaderan sebagai bentuk pengaplikasian dari trikompetensi dasar IMM. Karena itu untuk mewujudkan trikompetensi dasar. Perlu dilakukan pengembangan dan pembinaan kader. Selama ini, masih lebih dominan pada ranah intelektualitas. Padahal menurut saya. Harusnya religiusitas lebih diutamakan. Karena landasan trikompetensi dasar itu adalah Al-Qur'an dan as-sunnah. (Wawancara, 27/8/2020).

Ivan Wailoa(Kader IMM FAI) juga mengatakan bahwa:

Untuk menciptakan kader bangsa, kader umat dan kader persyarikatan. Yang paling utama adalah membangun kajian- kajian islam di tiap-tiap komisariat. Diantaranya 
adalah merevitalisasi pengurus secara total dan digodok kembali dalam kerohanian. Secara pribadi. Kader-kader harus sadar bahwa IMM adalah mahasiswa yang religius. Memperbaiki diri dan menjadi tauladan bagi yang lain. yang saya rasakan hanya intelektualitas dan humanitas saja. Karena kedua itu saja yang menonjol pada IMM di UMMU. Adapun Religiusitas masih jauh dari yang diharapkan (Wawancara, 27/8/2020).

Mus (Kader IMM Fai) mengatakan " Ruh dari Muhammadiyah sudah hilang dari kader- kader IMM"

Pada gambar berikut responden memberikan makna tentang trikompetensi dasar (intelektualitas, humanitas dan religiusitas) sebagai pijakan bagi kader IMM di UMMU untuk melahirkan ciri kader bangsa, kader umat dan kader persyarikatan:

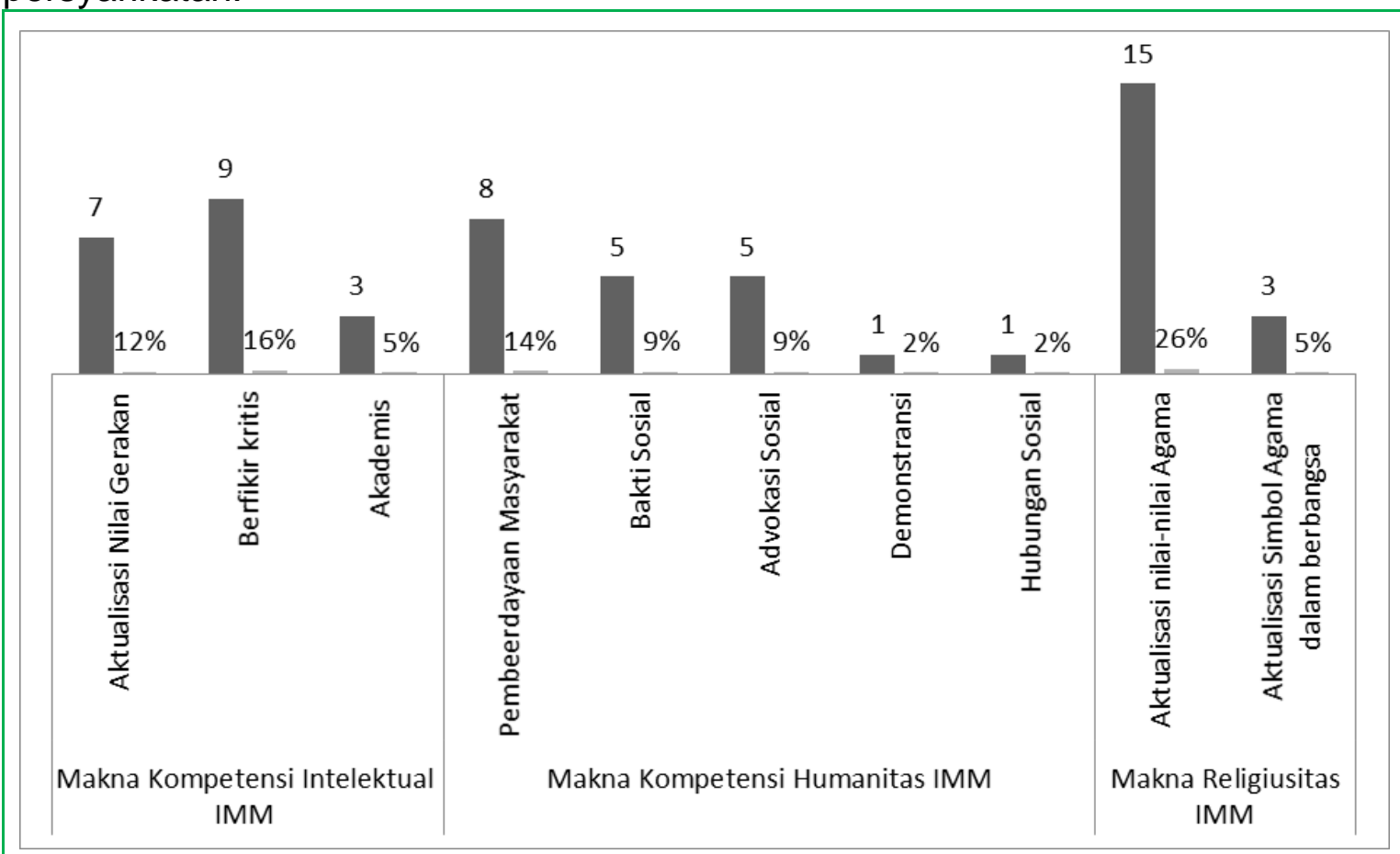

Gambar 8. Makna Trikompetensi IMM UMMU

Gambar 8 di atas secara spesifik, para responden memberikan makna intelektualitas pada tiga aspek yaitu berfikir kritis sebanyak $16 \%$, aktualisasi nilai gerakan dengan $12 \%$ dan makna intelektualitas sebagai keprofesian atau akademis sebanyak 5\%. Dengan demikian berfikir kritis adalah makna intelektualitas yang dominan dipahami oleh kader IMM UMMU.

Sementara kompetensi Humanitas dimaknai oleh kader imm sebagai pemberdayaan masyarakat sebanyak 14\%, bakti sosial dan advokasi sosial masing-masing 9\%, demonstrasi dan hubungan sosial masing-masing $1 \%$. Dengan demikian pemberdayaan masyarakat dimknai oleh sebagian besar responden sebagai poin penting dalam transformasi humanitas pada kader IMM di UMMU.

Sementara makna beragama atau aspek religiusitas oleh kader IMM dimaknai sebagai aktualisasi nilai-nilai agama sebanyak $26 \%$ dan $5 \%$ menanggapi religiusitas sebagai makna aktulisasi simbol beragama dalam berbangsa. 
Respon terhadap makna intelektualitas, humanitas dan religiusitas tersebut memberikan harapan baru tentang keberpihakan para kader IMM di UMMU dalam merespon situasi bangsanya. Walaupun memang pandangan tersebut di atas masih sebatas idea atau keyakinan para kader terhadap aspek trikompetensi. Dan belum bertransformasi menjadi program yang terstruktur dan mejadi kebiasaan bagi kader dalam melakukan proses kaderisasinya. Hal tersebut dibuktikan dengan pandangan para responden dalam visualisasi data pada gambar berikut:

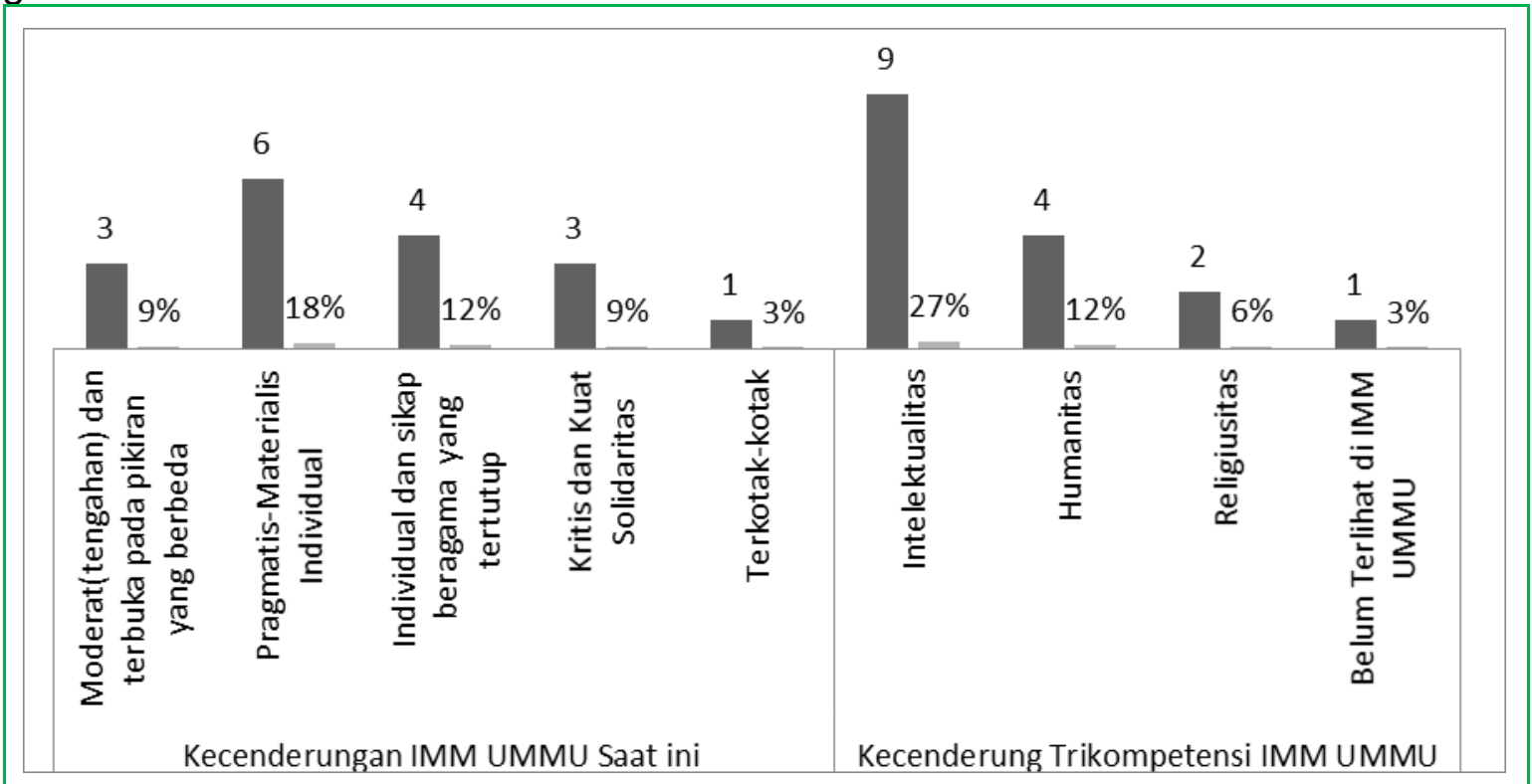

Gambar 9. Kecenderungan Kader dan Kecenderungan Perkaderan Trikompetensi IMM UMMU

Gambar 9 tersebut di atas tersampaikan bahwa kecenderungan orientasi kader IMM di UMMU menempatkan Intelektualitas sebagai poin utama dalam proses pengembangan dirinya dengan $27 \%$ responden. Sementara pada posisi kedua adalah aspek humanitas dengan $12 \%$ responden semenatara aspek religiusitas yang harusnya menjadi dasar utama bagi semua dimensi proses perkaderan di IMM UMMU justeru hanya mendapat 6\% dan 3\% sisanya mengatakan ketiga trikompetensi justeru belum terlihat di IMM UMMU.

Ketika ditanya tentang orientasi atau kecenderungan IMM UMMU saat ini responden mengatakan para kader IMM di UMMU cenderung material-individual sebanyak 18\%, individual dan sikap beragamanya tertutup sebanyak $12 \%$, moderat dan terbuka sebanyak $9 \%$, kritis dan kuat solidaritas sosialnya $9 \%$ dan terkotak-kotak sebanyak 3\%. Dari data tersebut dapat dibaca bahwa ruang idealitas pada makna trikompetensi tidak berbanding lurus dengan kenyataan yang terjadi. Dimana proses perkaderan belum mampu menjawab nilai-nilai idealitas dan keresahan kader.

\subsection{Persoalan Mikro Obyektif}

Persoalan mikro obyektif adalah persoalan tindakan dan pola perkaderan berbasis wawasan kebangsaan di era post-turst. Persoalannya tidak mudah untuk dipecahkan karena harus berhadapan dengan situasi dimana kader IMM UMMU tidak saja menghadapi persoalan eksternal yang kompleks tetapi juga persoalan 
internal yang tidak selesai dan terselesaikan. Sebagaimana terlihat pada gambar 10 berikut:

\begin{tabular}{|c|}
\hline $\begin{array}{l}\text { Nilai Etis hanya formalitas } \\
\text { Pola perkaderan di IMM UMMU } \\
\text { sebagaimana di SPI memang } \\
\text { belum atau bahkan tidak ada } \\
\text { Tidak ada pendampingan } \\
\text { Perkaderan pasca DAD } \\
\text { Yang ada hanya Persoalan } \\
\text { internal sesama kader } \\
\text { Kader-kader apatis dan mencari } \\
\text { jalan sendiri }\end{array}$ \\
\hline
\end{tabular}

Gambar 10. Persoalan Mikro Obyektif Perkaderan IMM UMMU

Gambar 10 tersebut di atas memperlihatkan persoalan internal IMM di UMMU yang berkaitan dengan proses perkaderan. $34 \%$ responden yang mewakili seluruh komisariat yang ada di UMMU, pengurus Koordinator Komisariat UMMU dan pimpinan Cabang sebagai informan mengatakan tidak ada pendampingan perkaderan pasca pelaksanaan Darul Arqam Dasar (DAD) IMM. Perlu diketahui DAD adalah pelatihan awal bagi kader IMM dan sesuai Sistem Perkaderan Ikatan (SPI) pasca DAD harus dilakukan pendampingan kepada kader yang baru menyelesaikan proses training dasar atau DAD tersebut.

Fadila Nyongali (Sekretaris IMM FIP UMMU) mengatakan:

Pola perkaderan di IMM UMMU sebagaimana di SPI memang belum atau bahkan tidak ada kegiatan yang sifatnya sistematis dengan rapi. Tidak ada pendampingan Perkaderan. Melihat problem sosial tetapi tidak ada reaksi. Dimanapun kita berada. Kita tetap berlomba dalam kebaikan. Yang ada hanya Persoalan internal sesama kader (Wawancara, 27/8/2020).

\section{Begitupun Roby Darwis (Sekretaris IMM Hukum) mengatakan:}

Tidak ada pengawalan pasca DAD dan akhirnya menurun kesadaran berorganisasi. Kader-kader apatis dan mencari jalan sendiri. Atau bertanya persoalannya ke seniorsenior organisasi lain". Sementara Rusnia Samiun mengatakan " IMM UMMU harus lebih giat dalam mengembangkan kajian-kajian dan agenda-agenda kebangsaan. Baik yang sifatnya internal maupun yang sifatnya eksternal. Karena selama ini pola perkaderan dalam mewujudkan trikompetensi maupun dalam rangka menyiapkan sebagai kader umat, kader bangsa dan kader persyarikatan belum terpola. (Wawancara, 27/8/2020).

Karena itu $22 \%$ reponden mengatakan pola perkaderan IMM di UMMU sebagaimana yang ada di SPI belum atau bahkan tidak ada. Hal tersebut bisa terjadi karena persoalan internal yang terus menerus merintangi proses dan tidak terselesaikan, 11\% responden mengatakan memang selama ini IMM UMMU hanya disibukan dengan persoalan internal yang menyebabkan agenda-agenda IMM yang lebih besar dan yang harus menjadi perhatian perkaderan seperti persoalan kebangsaan dan keumatan terabaikan. $11 \%$ responden juga mengatakan ego personal seringkali mengemuka dan mengabaikan kepentingan 
organisasi itulah menjadi sebab kenapa IMM UMMU hanya berhenti pada persoalan internal.

Sebagaimana yang disampaikan ketua Cabang IMM Kota Ternate Zulkarnain Pina bahwa:

Selama ini kita tidak mendorong visi-misi secara bersama karena faktor ego personal. Karena itu yang perlu di dorang adalah sikap cinta belajar dan giat berfikir. Harus menjadi generasi Rabbani dan Alilalbab. Proses perkaderan itu Meliputi proses struktural dan pola-pola kultural.

Selain persoalan tersebut, hal mendasar yang disoroti para kader IMM di UMMU adalah nilai etis religiusitas belum menjadi perilaku para kader terutama juga para instruktur. Karena itu M. Gadri Sanaba (Kader IMM Fai) mengatakan bahwa:

Persoalan pokok utama di IMM adalah masalah keinstrukturan. dimana Al-Qur;an dan As-sunanh sebagai dasar perkaderan tapi, yang buat saya tidak sepakat itu pada aplikasinya. Atau nilai etis tersebut hanya formalitas. Tidak ada prakteknya. Seperti tidak sholat dan merasa biasa-biasa saja. Wawancara, 27/8/2020).

Begitupula Sahmardan mengatakan bahwa:

IMM itu sesuai dengan AI-Quran dan sunnah. Mereka sangat konsisten dengan shlat berjamaah. Sesuai dengan tafsir surah Al-Ikhlas dan al-Maun. Namun yang terlihat di sini di UMMU Shalat tidak tepat waktu, karena itu tugas kita adalah Memurnikan yang terkontaminasi dengan hal-hal barat, Mulailah hal-hal yang kecil, seperti Sholat 5 Waktu. Pola komunikasi atau pergaulan Immawan dan Immawati perlu dijaga (Wawancara, 27/8/2020).

\subsection{Model Perkaderan Imm Ummu; Suatu Tawaran}

Sebagai respon terhadap dinamika pendidikan kader IMM Universitas Muhammadiyah Maluku Utara(UMMU) maka model perkaderan IMM UMMU berjalan pada garis pendulum religiusitas, intelektualitas, humanitas dan penokohan. Bahwa perkaderan tidak boleh terputus dan berjalan sendiri-sendiri atau mengkotak-kotakan hanya pada satu aspek kompetensi saja tetapi harus menyeluruh dan dimulai dari penguatan kompetensi religiusitas sebagai basis awal geneologi gerakan IMM UMMU, kemudian penguatan basis ilmu, pengetahuan dan kapasitas pada aspek intelektualitas, penguatan humanitas sebagai orientasi transformasi kemanusiaan dan proses penokohan sebagai Transformasi dan diaspora kader pada level kepemimpinan kepemudaan, Desa, NGO, birokrasi, dan politik.

Untuk mencapai maksud tersebut maka model $4 \mathrm{M}$ digunakan sebagai tahapan dan model pendidikan kader IMM UMMU. Dimulai dari Makro objektif (Penguatan geneologi pemikiran dan basis Keorganisasian). Yaitu memberikan basis keilmuan, pengetahuan dan kapasitas kader secara makro baik pada aspek Religiusitas, intelektualitas, humanitas dan penokohan.

Sementara pada aspek Makro subjketif(Penguatan budaya dan nilai kepemimpinan) adalah model perkaderan kepemimpinan dengan penguatan pada aspek budaya, norma dan nilai-nilai kepemimpinan universal. Tetapi syarat utama memasuki perkaderan makro subjektif adalah minimal telah dinyatakan lulus pada tahapan kompetensi perkaderan makro objektif. 
Pada Mikro Objektif (Pola tindaka atau perilaku Tauhid yang teladan, moderat, terbuka dan toleran) adalah model perkaderan yang menekankan pada aspek sikap dan tindakan transformasional kader. Serta perkaderan pada mikro subyektif (Prinsip Ketauhidan, peneguhan sikap intelektualitas dan keberpihakan).

Dalam melakukan penguatan teoritik-aplikatif pada tiga tahapan kompetensi dasar utam harus di lakukan secara menyeluruh dan tidak boleh dirubah tahapannya yaitu, dimulai dari tahapan perkaderan kompetensi Religiusitas, intelektual dan humanitas serta penguatan proses penokohan kader.

Dengan demikian maka model perkaderan dilakukan secara berjenjang dan berkelanjutan yang disebut dengan perkaderan empat $M(4 \mathrm{M})$. Yaitu level perkaderan Makro Objektif, Makro Subyektif, Mikro Objektif dan Perkaderan Mikro Subjektif. Digambarkan sebagai berikut:

Tabel 3. Model perkaderan 4M IMM Universitas Muhamadiyah Maluku Utara

\begin{tabular}{|c|c|c|c|c|}
\hline Fokus & Religiusitas & $\begin{array}{l}\text { Intelektualita } \\
\mathrm{s}\end{array}$ & Humanitas & Penokohan \\
\hline $\begin{array}{l}\text { Makro } \\
\text { Objektif } \\
\text { (Penguatan } \\
\text { geneologi } \\
\text { pemikiran dan } \\
\text { basis } \\
\text { Keorganisasi } \\
\text { an) }\end{array}$ & $\begin{array}{l}\text { [1] Risalah } \\
\text { Kenabian, [2] } \\
\text { Studi } \\
\text { Pemikiran } \\
\text { Islam [3] } \\
\text { Kajian } \\
\text { Pemikiran } \\
\text { Tokoh Dan } \\
\text { Perjuangan } \\
\text { Muhammadiy } \\
\text { ah } \\
\text { Sejarah dan } \\
\text { dinamika } \\
\text { Relasi } \\
\text { Agama dan } \\
\text { Negara }\end{array}$ & $\begin{array}{l}\text { [1] Sejarah } \\
\text { Filsafat } \\
\text { Barat [2] } \\
\text { Filsafat IImu } \\
\text { [3] } \\
\text { Paradigma- } \\
\text { paradigma } \\
\text { Ilmu Sosial } \\
\text { [4] Ideologi- } \\
\text { ideologi } \\
\text { Besar Dunia } \\
\text { [5] Ekonomi } \\
\text { Politik }\end{array}$ & $\begin{array}{l}\text { [1] Sejarah } \\
\text { Ummat } \\
\text { Manusia } \\
\text { Filsafat } \\
\text { Manusia } \\
\text { Pandangan } \\
\text { agama-agama } \\
\text { tentang } \\
\text { manusia } \\
\text { Pancasila dan } \\
\text { manusia } \\
\text { Indonesia }\end{array}$ & $\begin{array}{l}\text { Narasumber } \\
\text { pada kajian, } \\
\text { seminar } \\
\text { maupun } \\
\text { kolokium }\end{array}$ \\
\hline
\end{tabular}

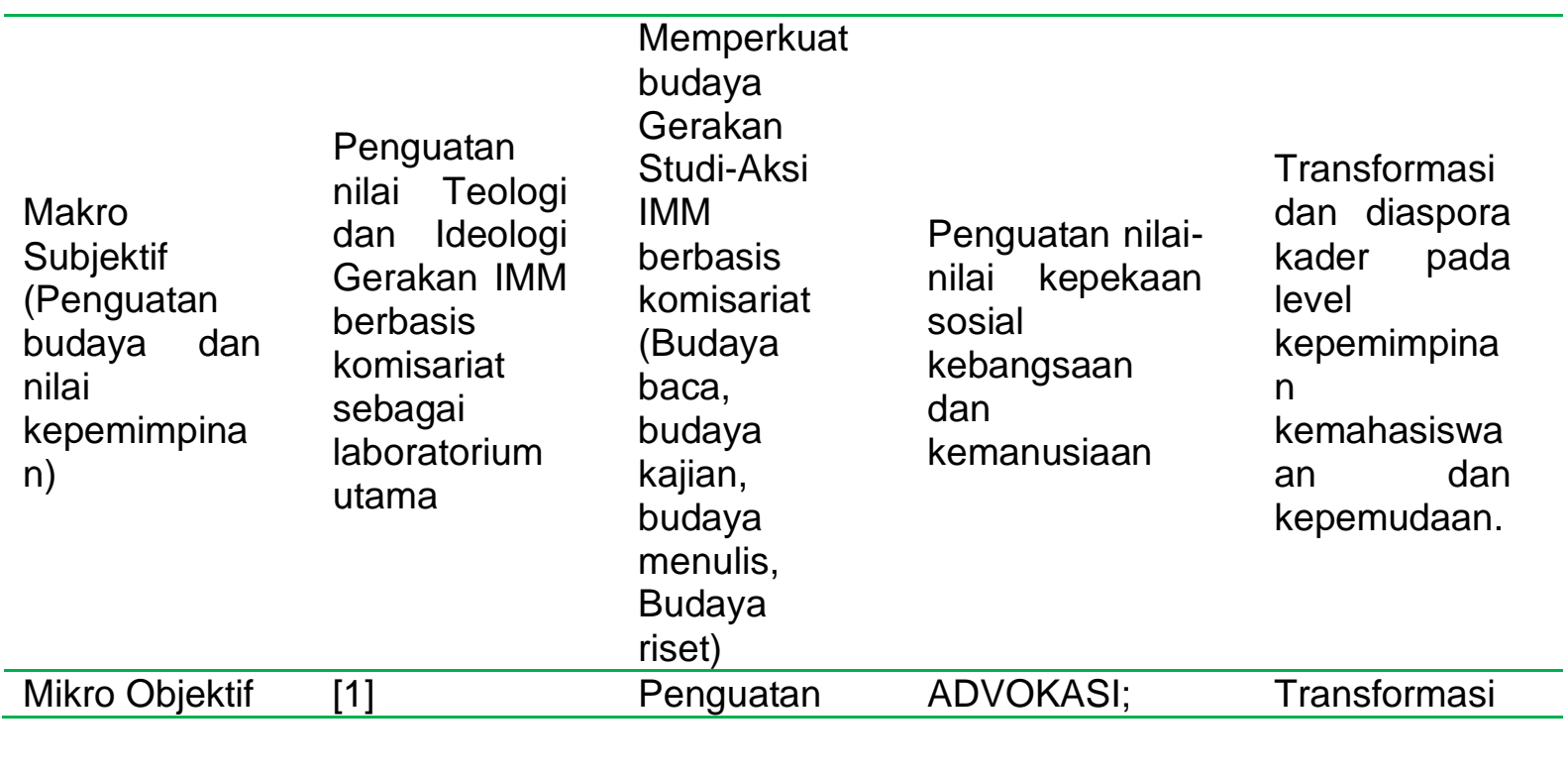




\begin{tabular}{|c|c|c|c|c|}
\hline $\begin{array}{l}\text { (Pola tindaka } \\
\text { atau perilaku } \\
\text { Tauhid yang } \\
\text { teladan, } \\
\text { moderat, } \\
\text { terbuka dan } \\
\text { toleran). }\end{array}$ & $\begin{array}{l}\text { Silaturahim } \\
\text { tokoh } \\
\text { Muhammadiy } \\
\text { ah dan Tokoh } \\
\text { Islam lainnya } \\
\text { [2] } \\
\text { Menciptakan } \\
\text { kerukunan } \\
\text { antar umat } \\
\text { beragama } \\
\text { [3] } \\
\text { Penguatan } \\
\text { kapasitas } \\
\text { Mubalig }\end{array}$ & $\begin{array}{l}\text { kapasitas } \\
\text { teoritik- } \\
\text { aplikatif } \\
\text { Workshop } \\
\text { Legal } \\
\text { Drafting, } \\
\text { Workshop } \\
\text { membaca } \\
\text { APBD, } \\
\text { pengawalan } \\
\text { UU, PP, } \\
\text { Perda, } \\
\text { Perdes dan } \\
\text { pendamping } \\
\text { an implikasi } \\
\text { kebijakan). }\end{array}$ & $\begin{array}{l}\text { Perlindungan } \\
\text { terhadap kaum } \\
\text { miskin kota dan } \\
\text { Desa yang } \\
\text { diakibatkan oleh } \\
\text { kebijakan yang } \\
\text { tidak berpihak } \\
\text { Serta } \\
\text { melaksanakan } \\
\text { PEMBERDAYA } \\
\text { AN } \\
\text { MASYARAKAT }\end{array}$ & $\begin{array}{l}\text { dan diaspora } \\
\text { kader pada } \\
\text { level } \\
\text { kepemimpina } \\
n \\
\text { kepemudaan, } \\
\text { Desa, NGO, } \\
\text { birokrasi, dan } \\
\text { politik. }\end{array}$ \\
\hline $\begin{array}{l}\text { Mikro } \\
\text { Subjektif } \\
\text { (Prinsip } \\
\text { Ketauhidan, } \\
\text { peneguhan } \\
\text { sikap } \\
\text { intelektualitas } \\
\text { dan } \\
\text { keberpihakan } \\
\text { ) }\end{array}$ & $\begin{array}{l}\text { Peneguhan } \\
\text { Prinsip } \\
\text { Ketauhidan }\end{array}$ & $\begin{array}{l}\text { Peneguhan } \\
\text { Prinsip } \\
\text { Intelektualita } \\
\text { s }\end{array}$ & $\begin{array}{l}\text { Peneguhan } \\
\text { Prinsip } \\
\text { Keberpihakan }\end{array}$ & $\begin{array}{l}\text { Kepemimpina } \\
\mathrm{n} \quad \text { Tauhid } \\
\text { yang } \\
\text { moderat, } \\
\text { terbuka, } \\
\text { toleran dan } \\
\text { teladan. }\end{array}$ \\
\hline
\end{tabular}

Tabel tersebut di atas adalah model perkaderan berbasis wawasan kebangsaan sebagai jawaban terhadap persoalan perkaderan di internal IMM Universitas Muhammadiyah Maluku Utara.

\section{Kesimpulan}

Mencermati persoalan perkaderan berbasis kebangsaan di era Post-Trust yang dilaksanakan oleh IMM UMMU memang tidak berdiri sendiri. Karena berhadapan dengan situasi eksternal yang datang dan melaju begitu cepat. Dalam teori integrasi sosiologi Ritzer disebut dengan situasi makro objketif dan makro subyektif seperti sitausi Masyarakat, bahasa, teknologi, norma, budaya dan nilai-nilai eksternal yang memaksakan individu untuk melakukan sebagaimana yang dipilihkan situasi eksternalnya.

Dalam pandangan Ritzer, situasi eksternal di atas disebut sebagai paradigma fakta sosial memusatkan perhatiannya pada struktur dan institusi sosial berskala makro. Model yang digunakan teoritisi fakta sosial adalah karya Emile Durkheim. Bahwa fakta sosial terdiri atas Fakta sosial material dan fakta sosial immaterial. Dalam paradigma fakta sosial ini, individu tidak berdaya karena di atur oleh kekuatan eksternalnya. Bahkan kesadarannya suda dipilihkan pada kesadaran material yang pada akhirnya memunculkan sikap apatis, tidak peduli dan nyaman dengan diri sendiri.

Pada situsi demikian, solidaritas mekanis berupa ikatan emosional dan kekeluargaan mulai terkikis dan tergantikan oleh kesadaran solidaritas organik. Yaitu kesadaran solidaritas berdasarkan ketergantungan pembagian kerja (Division of labor). Pada tahap yang plaing krusial adalah pertemanan atau 
ikatan solidaritasnya didasari oleh kepentingan personal dan mengabaikan kepentingan bersama karena di dorong oleh motif material atau motif memperkaya diri sendiri bahkan motif kuasa(Politik kekuasaan).

Fakta sosial tersebut tentunya sangat mempengaruhi organisasi perkaderan seperti IMM. Terbukti 18\% kader IMM merespon bahwa orientasi atau kecenderungan IMM UMMU saat ini adalah material-individual, menyusul sikap beragamanya tertutup sebanyak $12 \%$, moderat dan terbuka sebanyak $9 \%$, kritis dan kuat solidaritas sosialnya 9\% dan terkotak-kotak sebanyak 3\%. Dari data tersebut dapat dibaca bahwa ruang idealitas pada makna trikompetensi tidak berbanding lurus dengan kenyataan yang terjadi. Dimana proses perkaderan belum mampu menjawab nilai-nilai idealitas dan keresahan kader.

Paradigma kedua adalah Definisi Sosial. Yaitu, berkaitan dengan tindakan sosial (social action) Max Weber. Bagi Weber, pokok persoalan masyarakat adalah; bagaimana memahami tindakan sosial dalam interaksi sosial, dimana "tindakan yang penuh makna, ditafsirkan. Orientasi tindakan sosial Weber dibagi menjadi tindakan sosial berorientasi rasional instrumental, berorientasi nilai, berorientasi afektif dan berorientasi tradisional.

Maka makna perkaderan Trikompetensi Dasar IMM UMMU sebagaimana tersebut pada gambar 8. Hal. 14. Menempatkan makna perkaderan intelektual pada tiga kategori yaitu, aktualisasi nilai gerakan dengan 12\% berfikir kritis $16 \%$ dan akademis $5 \%$. Itu artinya ada problem serius soal pengembangan keilmuan dan keprofesian yang menempatkan aspek akademis pada level terendah dalam kompetensi intelektual. Intelektual diberi makna sebagai upaya menelaah dan menjawab problem-problem keumatan dengan mengkampanyekan ide-ide kekritisan sebagai bentuk aktualisasi nilai-nilai gerakan.

Tetapi berbeda ketika ditanya tentang makna perkaderan humanitas maka demonstrasi justeru ditempatkan pada level terendah dengan $2 \%$ bersama hubungan sosial $2 \%$. sementara pemberdayaan masyarakat berada posisi tertinggi dengan $26 \%$ di susul bakti sosial $9 \%$ dan Advokasi sosial $9 \%$. Begitupun makna perkaderan religiusitas menempatkan aktualisasi nilai agama pada posisi tertinggi dengan $26 \%$ dan aktualisasi simbol agama dalam berbangsa dengan $5 \%$.

Dalam aspek humanitas dan religiusitas tindakan kader IMM UMMU bisa dipahami sebagai sebuah tindakan berorientasi nilai pembebasan dan emansipatif ketika menempatkan pemberdayaan masyarakat dan advokasi sosial pada pemaknaan tertinggi aspek humanitas dan substansi beragama pada pemaknaan aspek religiusitas.

Tetapi jika dilihat dengan menggunakan Paradigma Perilaku Sosial, dimana menekankan pada 'perilaku individu yang tak terpikirkan'. Fokus utamanya pada rewards sebagai stimulus berperilaku yang diinginkan, dan punishment sebagai pencegah perilaku -yang tidak diinginkan. Maka secara praktis IMM UMMU dalam penelitian ini telah memberikan otokritik pada dirinya sendiri ketika ide, harapan pikiran-pikiran kritisnya tidak sejalan dengan realitas semestinya. Sebagaimana tersebut pada 15 persoalan makro obyektif perkaderan IMM UMMU di hal.12. 


\section{UCAPAN TERIMAKASIH}

Ucapan terima kasih penulis ucapkan terima kasih kepada Kemenristekdikti dan LLDikti Wilayah XII Maluku dan Maluku Utara atas kepercayaannya memberikan dana hibah terhadap penelitian ini. Selanjutnya, ucapan terima kasih penulis ucapkan kepada Ketua Yayasan Universitas Muhammadiyah Maluku Utara, Rektor Universitas Muhammadiyah Maluku Utara, dan LPPPM Universitas Muhammadiyah Maluku Utara atas dukungan sehingga penelitian ini dapat selesai tepat waktu.

\section{Daftar Pustaka}

Fatah, A. R. (2019). Menyoal Keberagamaan dan Politik Identitas di Era Pos-Truth. Malut Post.

Hadi, H. O. (2019). Nation and Character Building Melalui Pemahaman Wawasan Kebangsaan. Retrieved November 8, 2020, from Bappenas website: https://www.bappenas.go.id/files/8613/5763/0713/otto__20091015095838_2 $297 \_0 . d o c$

Hartono, D. (2018). Era Post-Truth : Melawan Hoax dengan Fact Checking. Prosiding Seminar Nasional Prodi IImu Pemerintahan 2018 Era.

Hasnan, B. (2010). Dar al-'Ahd Wa Al-Shahadah: Upaya dan Tantangan Muhammadiyah Merawat Kebinekaan. MAARIF, 14(1).

Isnanto, M. (2017). Gagasan dan Pemikiran Muhammadiyah Tentang Kaderisasi Ulama (Studi Kasus tentang Ulama di Muhammadiyah. Jurnal Aplikasi IImuIlmu Agama, 17(2), 95-108.

Kusmayadi, Y. (2017). Hubungan Antara Pemahaman Sejarah Nasional Indonesia dan Wawasan Kebangsaan Dengan Karakter Mahasiswa (Studi Pada Mahasi swa Pendidikan Sejarah FKIP Universitas Galuh Ciamis). Agastya, 7(2).

Makhrus, A., \& Aminudin, A. (2014). Geneologi Kaum Merah; Pemikiran dan Gerakan. Yogyakarta: Rangkang Education.

Muflihah, D. L. (2017). Perkaderan Intelektual Pimpinan Cabang Ikatan Mahasiswa Muhammadiyah Kabupaten Sukuharjo. Tajdida, 15(1).

Rajiah, S., \& Rusydi. (2016). Peran Muhammadiyah (Konsep Pendidikan, Usahausaha di bidang Pendidikan dan Tokoh). Tarbawi, 1(2).

Romadlan, S. (2020). Diskursus Negara Pancasila di Kalangan Muhammadiyah. Sospol: Jurnal Sosial Politik, 6(1), 1-15. 